\title{
歩きスマホが反応時間および歩行動作に与える影響
}

\section{○小松 史旺（東京都立産業技術高専専攻科）}

小林 吉之（産業技術総合研究所）

持丸正明（産業技術総合研究所）

三林 洋介（東京都立産業技術高専）

Impact of smartphone use during walking has on reaction time and walking motions
Shio KOMATSU (Tokyo Metropolitan College of Industrial Technology)
Yoshiyuki KOBAYASHI(Advanced Industrial Science and Technology)
Masaaki MOCHIMARU(Advanced Industrial Science and Technology)
Yosuke SAMBAYASHI((Tokyo Metropolitan College of Industrial Technology)

\section{1.はじめに}

現在スマートフォンの普及率は増加傾向にあり 内閣府の消費動向調査によると平成26年3月末現 在 $54.7 \%$ にんでいる. 普及率に比例して近年問題 視されているのが歩きスマホである.従来の フィーチャーフォンと比較して、画面に表示され る情報量の増加や、すぐに取り出して操作するこ とのできる手軽さなどによって歩さスマホをする 人が増加、これによって引き起こされる事故も多 発し、2013年10月には死亡事故にまで至っている.

そこで本研究では、歩きスマホが主としてユー ザの反応時間および歩行動作に与える影響を探求 することを目的とする. 具体的には、歩きスマホ による注意の低下、歩行動作的変化に着目し、反 応時間、歩行ピッチ、身体動摇について通常歩行 と歩きスマホを行った際の変化を、実験を通して 測定評価した.

\section{2. 実験方法}

通常歩行時と歩きスマホ時の反応時間および歩 行動作特性を明らかにするためにトレッドミル （ランニングマシン）を用いた歩行計測実験を 行った.Ericらは人が歩きスマホや、携帯電話を 行う際に歩行速度が3割減速する(1)ことを明らか にしており、本実験のトレッドミルの速度は、被 検者ごとの通常歩行速度と、これらの3割減の速 度の2つの条件を設定し、各々の設定速度条件下 で通常歩行、スマホを行いながらの歩行を各々 3 分間実施した. また歩きスマホのタスクにはメモ 機能を利用し、名前/住所/電話番号/所属/出身/ 学歴/メールアドレスの項目を設定し、その項目 についての入力作業を課した.

\section{1反応時間、身体動摇測定実験}

被験者の $2 \mathrm{~m}$ 前方床面上にLED点灯部を固定設置 し、歩行中にLED点灯に気付いたら手元の応答ス イッチを押すように指示した.なお、LEDの点灯は 25秒〜40秒のランダムな間隔に設定した.

関節座標データの所得は動作計測装置 (kinect) によって自動的に取得が可能なため、反応時間の 測定と同時に前方にカメラを設置して連続測定を した. 被験者は心身共に健康な学生12名とした.

\section{2歩行ピツチ測定実験}

実験2.1に歩きスマホのタスクに動画の視聴作 業を追加し、2速度 3 条件下の計6条件で実験を 行った.動画には映画のワンシーンを使用し、 ヘッドフォンを装着して視聴作業を課した. 実験 には安全確保のため、被験者にハーネスを着用し 測定した.4つの力センサーを、トレッドミルの四 隅の直下に配置、4つのセンサーから得られる3 軸 の力成分のうち鉛直方向の力成分を合算して歩行 のピッチを求めた. 被験者は心身共に健康な若年 層10名とした。

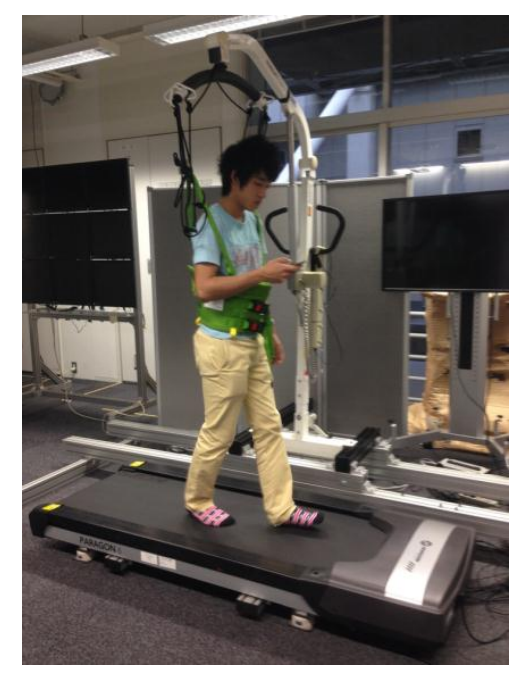

図1. 歩行ピッチ測定実験の様子 


\section{3. 結果と考察}

通常歩行と歩きスマホ中の歩行速度 2 条件 下における反応時間測定結果を図 2 に示寸.

図より通常歩行では速度による反応時間の 大きな相違は見られなかった. 通常歩行 (100\% 速度)の反応時間を基準にすると、歩きスマホ をすることによって同一歩行速度条件で $278.0 \%$ (約 3.8 倍), 70\%速度条件では $126.3 \%$ (約 2.3 倍)の反応時間の増加が見られた. すなわち 歩きスマホによる自然な速度減速に配慮して も反応時間の顕著な増加が明らかとなった. 核 実験条件別の反応時間を統計的に比較するた め、反応時間を因子として一元配置分散分析 を行ったところ、100\%速度の通常歩行と 70\%速 度の歩きスマホの間で有意差 $(\mathrm{p} \leq 0.05)$ が認 められた。

次に歩きスマホ時の身体動摇度について考 えるために被験者の歩行中の両肩の中心座標 変化を最大ブレ幅として $\mathrm{x}$ 軸座標(前額面)の 最大值と最小值の差分を求めたところ、通常 歩行時に比較して歩きスマホ時には約 30\%差分 值が大きい.このことから歩きスマホによって 歩行動動摇度が大きくなることが明らかと なった. 同様に両肩の中心点を参照点とし、 xyz 軸の合成ベクトルを算出、センサーからの 距離の変化から、歩行姿勢の経時的変化を検 討した. その結果、 $\mathrm{x}$ 軸座標のみで明らかとし た歩行動摇の変化と同様の結果が得られた.

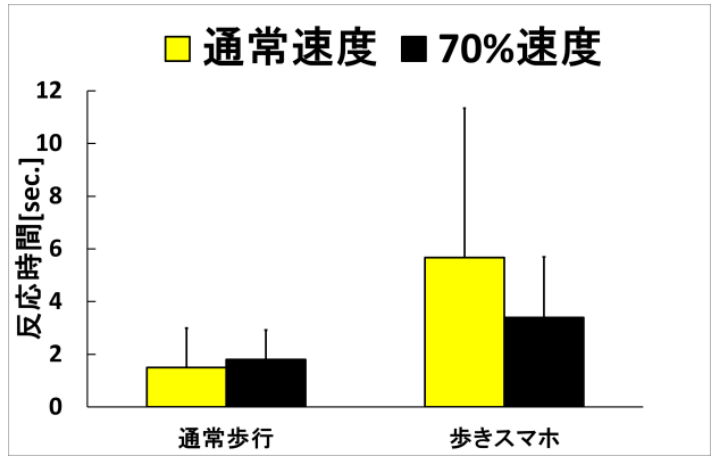

図 2. 通常歩行と歩きスマホの反応時間

通常歩行と歩きスマホ (動画視聴)、歩きス マホ(文字入力)、各々における速度 2 条件下 の歩行ピッチを図 3 に示す. 図より、3 条件 (スマホの有無) の間でピッチの平均值に変 化はみられず速度条件でのみピッチの平均值 に差が見られた.また、実験各条件別によって
得られた歩行ピッチを統計的に比較するため、 速度条件とタスクの 2 水準でピッチを因子と した二元配置分散分析を行ったところ、速度 間で歩行ピッチに有意差 $(\mathrm{p} \leq 0.01)$ が認めら れた. スマホによる減速の影響を踏まえると歩 きスマホをすることは直接歩行ピッチに影響 はないものの、歩きスマホを行うことによる 減速が歩行ピッチに影響しており、歩きスマ ホによって間接的に歩行ピッチの変化に影響 を与えていることが考えられる.上松らは歩行 ピッチの変化が歩行の直進性に影響を与える ${ }^{(2)}$ ことを明らかにしている.この影響を踏まえる と、歩きスマホをすることによってピッチの 変化に影響を与え、その結果として直進性の 低下一至ることが考えられる。

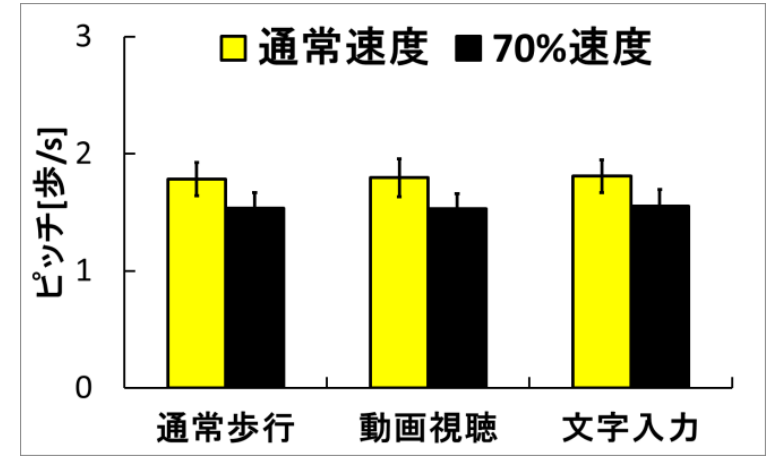

図 3. 歩きスマホによるピッチの変化

\section{4.まとめ}

歩きスマホを行うことで通常歩行速度では約 3.8倍、スマホ使用による減速を加味した $70 \%$ 歩行 速度で約 2.3 倍もの前方注意反応時間に有意な遅 れが生じる. 身体動摇についても通常速度で約 30\%,70\%速度で約23\%最大ブレ幅の増加が見られた。 また、歩行速度が減速することで歩行ピッチが小 さくなり直進性の低下に影響を与えることを明ら かにした.

\section{参考文献}

1) Eric M. Lamberg他: Cellphones change the way we walk. Gait\&Posture , 2011.

2) AzusaUematsu他 : Preferred step frequency minimizes veering during natural human walking. Neuroscience Letters ,2011.

3）増田康祐, 芳賀繁: 携帯電話への文字入力が注 意、歩行、メンタルワークロードに及ぼす影 響, 日本人間工学会誌, Vol. 51, No. 1, p5261, 2015 